\title{
Stress Management In Women Working During The Covid-19 Pandemic In Sidokumpul Village, Bungah, Gresik
}

\author{
Yurike Septianingrum $^{1 *}$, Lono Wijayanti ${ }^{2}$, Erika Martining Wardani ${ }^{3}$
}

${ }^{1}$ Nurse and Midwifery Faculty/Nahdlatul Ulama University Surabaya, SMEA Street On .57/Surabaya

${ }^{2}$ Nurse and Midwifery Faculty/Nahdlatul Ulama University Surabaya, SMEA Street On .57/Surabaya

${ }^{3}$ Nurse and Midwifery Faculty/Nahdlatul Ulama University Surabaya, SMEA Street On .57/Surabaya

*E-mail: yurikesepti1209@unusa.ac.id

\begin{tabular}{llll} 
Article submitted & $: 6$ Januari & 2021 \\
Review article & $:$ 14 Februari 2021 \\
Accepted article & $: 3$ Maret & 2021 \\
\hline
\end{tabular}

\begin{abstract}
The dual role of being a mother and a worker gives stress to women who live it. The demand to work at home becomes a burden for them because they have to optimize their roles both as mothers and as workers, especially in conditions of imbalance in the work environment due to the current Covid-19 pandemic. The mother's inability to cope with the stressors received has the risk of causing depression in the mother. This community service aims to increase knowledge of mothers about stress management in working mothers during the Covid19 pandemic. The activities are carried out within 1 month. The method used is education and demonstration of positive thinking virtually via YouTube. This community service activity was attended by 17 mothers. Mother's knowledge was measured using a questionnaire via google form. The results of community service show that there is an increase in knowledge of mothers after being given virtual counseling.
\end{abstract}

Keywords: stress management; working mother; covid-19; health education.

\section{Abstrak}

Peran ganda sebagai seorang Ibu dan pekerja memberikan stres bagi wanita yang menjalaninya. Tuntutan untuk bekerja di rumah menjadi beban tersendiri bagi mereka karena harus mengoptimalkan peran baik sebagai Ibu dan sebagai pekerja, terlebih dalam kondisi ketidakseimbangan lingkungan kerja akibat pandemi Covid-19 yang terjadi saat ini. Ketidak mampuan ibu mengkoping stresor yang diterima beresiko mengakibatkan depresi pada ibu. Pengabdian masyarakat ini bertujuan untuk meningkatkan pengetahuan pada ibu mengenai manajemen stres pada ibu bekerja selama pandemi Covid-19. Pelaksanaan kegiatan dilakukan dalam jangka waktu 1 bulan. Metode yang dilakukan adalah edukasi dan demonstrasi cara berpikir positif secara virtual melalui youtube. Kegiatan pengabdian masyarakat ini diikuti oleh 17 ibu. Pengetahuan ibu diukur menggunakan kuesioner melalui google formulir. Hasil pengabdian masyarakat menunjukkan bahwa ada peningkatan pengetahuan pada ibu setelah diberikan penyuluhan virtual.

Kata Kunci: manajemen stres; ibu bekerja; covid-19; pendidikan kesehatan.

\section{INTRODUCTION}

The Covid-19 pandemic caused by the corona virus (Sars-CoV-2) has a broad global impact. The World Health Organization (WHO) declared the Covid-19 pandemic a "public health emergency of international concern". From the first case reported to the World Health Organization on December 31, 2019 to the total cases rapidly approaching one million in April 2020 (WHO, 2020). Indonesia is one of the countries affected by the spread of Covid-19, with a proven number of 5,923 confirmed positive COVID19 cases, while in East Java the Covid-19 cases reached 4857 cases (Kementerian Kesehatan RI, 2020). To prevent transmission of Covid-19, The Indonesian government recommends that people comply with health protocols and limit activities outside the home. The government requires students to study from home and advises workers to work from home (Spinelli et al., 2020; Wulandari et al., 2020). The phenomenon of mothers working is nothing new in Indonesia. The facts presented by the Ministry of Women's Empowerment and Child Protection (2018) state that nearly $51 \%$ of Indonesia's working population is a woman. Other information also states that the 
participation rate of women who play a role in managing the household and working outside the family is also very high, reaching over $46 \%$. Even when compared to men, the percentage of women who are married at the same time they are also workers reaches $71 \%$, only 5\% different from the number of men who reach $76 \%$ (Kementerian Pemberdayaan Perempuan dan Perlindungan anak, 2019). This fact concludes that the participation and position of a working mother greatly determines how they build themselves and their families through work.

The Covid-19 pandemic caused sudden changes in family conditions, including the role of mothers. Working mothers are required to be multitasking mothers, in addition to acting as housewives as well as workers. Mothers as parents who often interact with their children and do parenting, of course, currently have additional duties as companions for children's learning during study from home. This is a change that can become a new stressor so that the mother experiences stress, tension and anxiety (Spinelli et al., 2020).

The government regulation to stay at home created new circumstances and new problems. Currently, many parents work at home and must accompany their children to study from home (Wulandari et al., 2020). Many parents are attempting to work remotely from home while caring for children. Parents with school-going children also face new demands of home-based schooling (Chung et al., 2020). These conditions can add to the many negative stressors that a mother who works at home may feel, which includes the pile of work that has to be done by mothers for many reasons, adaptation to the use of work media that may be most suitable if working from home virtually, needs and caring. to their children and husbands increases, and other things that every mother may feel differently when her office work has to be done at home. These conditions make them stressful because they are faced with multitasking activities (Thomeer et al., 2015)

Mothers who work from home have their own challenges because in addition to completing their work at home, they also have to assist their children to learn from home (study from home). Sometimes they complain of stress because of undergoing this duality of roles, accumulating task deadlines plus children's tasks which they sometimes lack mastery of. Problems arise when the mother is unable to cope with stress and takes her anger out on her husband and children (Hansel et al., 2020; Marliani et al., 2020).

Existing studies indicate that higher levels of parental stress are associated with poorer parenting related outcomes such as harsh parenting practices and poor parent-child relationships. As parental stress increases, researchers have warned about the increased risk of family violence and child abuse during this period when families remain at home with reduced community contact and external social support (Brown et al., 2020).

Currently, the stress on mothers who work from home and accompany their children to learn from home is not getting enough attention by health workers, even though this has a negative impact on the health of mothers and other family members because mothers have an important role in the family. Therefore, the service provider wants to provide health education about stress management in working mothers during the Covid-19 pandemic. It is expected that this activity can increase mother's knowledge and ability to manage stress well.

\section{SITUATION ANALYSIS}

\section{General Description}

Sidokumpul Village is one of the villages in Bungah District, Gresik Regency, East Java. This location is about $42.9 \mathrm{~km}$ from Unusa Campus A. The health facility there is the Bungah Health Center. The community service activity "Health Education for stress management of working mothers during the Covid-19 pandemic" targets mothers in Sidokumpul Village.

\section{Problems}

The results of interviews with 10 mothers showed that all mothers felt stress when they had to work from home and assist their children to study from home and most mothers (80\%) did not know how to deal with stress. All mothers interviewed said they had never been given health education about stress management during the Covid-19 pandemic. So far they have only been given counseling on the $3 \mathrm{M}$ health protocol (Using masks, 
washing hands, avoiding crowds). So far, health workers only focus on dealing with physical symptoms, but do not pay attention to the psychological disorders of the community, especially working mothers.

Education about stress management in working mothers needs to be given so that mothers can cope with the stressors so that mothers become calm in carrying out their roles because happy mothers are the key to family happiness.

\section{METHODS}

This method of implementing community service used a participative educational approach which is carried out as an effort to increase maternal knowledge about stress management in working mothers during the Covid19 pandemic with video has beeb appouded to you tubeThe target of this community service activity is noneconomic community groups, namely groups of working mothers in Sidokumpul Village. Discussions and Q\&A are carried out offline after participants have seen the educational video. The pre-test is given before starting the educational video, the pre test is in the form of a knowledge questionnaire via google form which contains 10 questions about the material. Post test is given at the end of the activity via google form. Filling out the questionnaire via google form was assisted by students. Pre-test and post-test is given to find out changes in mother's knowledge about stress management.

\section{RESULTS AND DISCUSSION}

The results achieved from the implementation of community service activities, with the title " stress management health education for working mothers during the Covid-19 pandemic" which was attended by 17 mothers in Sidokumpul Village are as follows:

Table 1.1 The Results of The Pretest and Posttest of Stress Management Knowledge in Working Mothers

\begin{tabular}{ccccc}
\hline \multicolumn{1}{c}{ Score } & Mean & SD & Min-Max. & $P$ \\
\hline Pre-test & 35.88 & 14.603 & $-46.594-35.579$ & 0.000 \\
Post-test & 77.06 & 14.476 & & \\
\hline
\end{tabular}

Based on Table 1.1 pre-test and post-test knowledge of libu as many as 17 respondents, it can be stated that the results of the pre-test about the respondents' knowledge of stress management were 2 mothers $(11.76 \%)$ who knew about stress management, and as many as 15 mothers $(88.24 \%)$ did not know new normal and stress management. Meanwhile, based on the post-test results, 43 mothers (93.48\%) knew about stress management, while 3 mothers $(6.52 \%)$ did not know about stress management.

Judging from the pre-test results, most of the respondents did not know what new normal was, signs and symptoms of stress, and stress management. However, after health education was carried out, the results of the post test most of the respondents knew about stress management.

Some mothers consider that the stress symptoms they face are normal for their mothers to experience so they don't feel they need help from health workers. Working mothers are prone to stress, especially faced with dual roles as workers and housewives. On average, mothers do not know how to deal with the stresses that arise so that this condition has an impact on disharmonious family relationships (Marliani et al., 2020).

The results of observations and interviews show that mothers in the village of Sidokumpul have increased knowledge about stress management. Educational methods through social media have also proven effective in educating the public. Other studies have shown that health education using multimedia methods is more effective than face-to-face methods in increasing knowledge and attitudes about breastfeeding and breastfeeding in Cirebon (Pepi Hapitria, 2017).

So far, health education has been provided through the lecture method, but due to the conditions of the Covid19 pandemic, health workers have to be creative in using technology to provide education to the public. Because most Indonesians are social media users, health education using social media is considered quite effective.(Masita, Elly Dwi, 2018) 


\section{CONCLUSION AND SUGGESTION}

Health education of stress management for working mothers who carry out work from home (WFH) during the Covid-19 pandemic can increase maternal awareness about stress management so that mothers are able to carry out dual role roles properly.

Health education online and uploaded on YouTube makes it easier for people, especially mothers, to access health information quickly and easily, but it must also be given a display or video that is more interesting and informative so that people do not get bored of participating in health education. It is hoped that community service can further provide health education by utilizing technology more creatively, such as the use of emodules

\section{REFFERENCES}

Brown, S. M., Doom, J. R., Lechuga-Peña, S., Watamura, S. E., \& Koppels, T. (2020). Stress and parenting during the global COVID-19 pandemic. Child Abuse and Neglect, August. https://doi.org/10.1016/j.chiabu.2020.104699

Chung, G., Lanier, P., \& Wong, P. Y. J. (2020). Mediating Effects of Parental Stress on Harsh Parenting and Parent-Child Relationship during Coronavirus (COVID-19) Pandemic in Singapore. Journal of Family Violence. https://doi.org/10.1007/s10896-020-00200-1

Hansel, T. C., Saltzman, L. Y., \& Bordnick, P. S. (2020). Behavioral Health and Response for COVID-19. Disaster Medicine and Public Health Preparedness, May. https://doi.org/10.1017/dmp.2020.180

Kementerian Kesehatan RI. (2020). Dokumen resmi. Pedoman Kesiapan Menghadapi COVID-19, 0-115.

Kementerian Pemberdayaan Perempuan dan Perlindungan anak. (2019). Profil Perempuan Indonesia. Profil Perempuan Indonesia.

Marliani, R., Nasrudin, E., Rahmawati, R., \& Ramdani, Z. (2020). Regulasi Emosi Stres dan Kesejahteraan Psikologis Studi Pada Ibu Work From Regulasi Emosi , Stres, dan Kesejahteraan Psikologis : Studi Pada Ibu Work from Home dalam Menghadapi Pandemi COVID-19. May.

Masita, E. D., \& Maimunah, S. (2018). IMPLEMENTASI TRIPLE C PARENTING IMPLEMENTASI TRIPLE C PARENTING PADA PENGASUH ANAK YANG MENGALAMI OBESITAS DINI USIA 3-5 TAHUN DI PAUD RW III KELURAHAN WONOKROMO. Community Development Journal, 2(2), 377-379.

Pepi Hapitria, R. P. (2017). Efektifitas Pendidikan Kesehatan Melalui Multimedia dan Tatap Muka terhadap Pengetahuan dan Sikap Ibu Hamil tentang Asi dan Menyusui. Jurnal Care, 5 no 2, 156-167.

Spinelli, M., Lionetti, F., Pastore, M., \& Fasolo, M. (2020). Parents' Stress and Children's Psychological Problems in Families Facing the COVID-19 Outbreak in Italy. Frontiers in Psychology, 11. https://doi.org/10.3389/fpsyg.2020.01713

Thomeer, M. B., Reczek, C., \& Umberson, D. (2015). Gendered emotion work around physical health problems in mid- and later-life marriages. J Aging Stud, 32(1), 12-22. https://doi.org/10.1016/j.jaging.2014.12.001.Gendered

WHO. (2020). Coronavirus Disease 2019 (COVID-19) Situation Reports. April 1 2020. WHO Situation Report, 2019(72), 1-19.

Wulandari, N. A., Rahmawati, A., \& Sari, Y. K. (2020). Meningkatkan Kesiapan Siswa TK Yaa Bunayya Lodoyo Untuk Menerapkan " New Normal Life " Pada Pandemi Covid 19. Community Development Journal, 4(2), 171-177. https://doi.org/10.33086/cdj.v4i2.1789 